\title{
PERTANGGUNGJAWABAN PIDANA KORPORASI YANG MELAKUKAN KORUPSI PENGADAAN BARANG DAN JASA
}

\author{
Marthin Simangunsong dan Sihol Marito Siregar ${ }^{2}$ \\ ${ }^{1,2}$ Program Studi Ilmu Hukum \\ Universitas HKBP Nommensen, Medan-Sumatera Utara-Indonesia \\ e-mail: marthin.simangunsong@uhn.ac.id
}

\begin{abstract}
A corporate criminal accountability is a corporate obligation to receive a reply for his crimes. These crimes can be appealed to corporations based on theories about how they handle criminal crimes. The study is aimed at understanding the form of corporate criminal accountability under the law no. 31 in 1999, Jo law no. 20 in 2001 on the elimination of corruption crimes, and understanding the corporate criminal accountability of those who are in the corruption management of goods and service ruling no.1 / ppd. SUS/ppd. PST. This study is a normative-law study, with legal sources being primary and secondary legal materials, with regulatory and case approaches, and is then studied descriptively by using deductive and inductive methods to address the problem. Based on research the authors conducted on corporate criminal accountability that underlie the 51st/pd. SUS/tipikor /2018/ pk. JKT. In the first semester of 2008, bank Indonesia the central bank/bi decided to raise its key rate by 25 basis points to 8.25 percent in the second quarter of this year.
\end{abstract}

Keywords: Corporate Criminal Accountability, Corruption, Procurement And Services

\begin{abstract}
Abstrak
Pertanggungjawaban pidana korporasi adalah kewajiban korporasi untuk menerima balasan akibat tindak pidana yang dilakukannya. Pertanggungjawaban pidana ini dapat dimintakan kepada korporasi berdasarkan teori-teori peranggungjawaban pidana korporasi. Penelitian ini bertujuan untuk memahami bentuk pertanggungjawaban pidana korporasi di dalam UndangUndang Nomor 31 Tahun 1999 jo Undang-Undang Nomor 20 Tahun 2001 tentang Pemberantasan Tindak Pidana Korupsi, dan memahami pertanggungjawaban pidana korporasi yang melakukan korupsi pengadaan barang dan jasa studi putusan nomor 81/Pid.Sus/Tipikor/2018/Pn.Jkt.Pst. Penelitian ini bersifat penelitian hukum normatif, dengan sumber bahan hukum adalah bahan hukum primer dan sekunder, dengan metode pendekatan perundang-undangan dan pendekatan kasus, kemudian dipelajari secara deskriptif dengan menggunakan metode deduktif dan induktif untuk menjawab permasalahan yang diteliti. Berdasarkan penelitian yang penulis lakukan tentang Pertanggungjawaban Pidana Korporasi yang Melakukan Korupsi Pengadaan Barang dan Jasa Studi Putusan Nomor 81/Pid.Sus/Tipikor/2018/Pn.Jkt.Pst, korporasi dapat diminta pertanggungjawaban pidananya, karena meskipun KUHP belum mengakui korporasi sebagai subjek hukum, Undang-Undang Pemberantasan Tindak Pidana Korupsi mengakui korporasi sebagai subjek hukum, sebagaimana tindak pidana yang dilakukan terdakwa PT.DGI ialah tindak pidana korupsi, yang dilakukan dengan melanggar ketentuan tentang pengadaan barang/jasa pemerintah. Selain daripada itu, Undang-Undang Pemberantasan Tindak Pidana Korupsi menganut teori pertanggungjawaban pidana korporasi yaitu teori identifikasi dan teori agregasi, sehingga korporasi dapat dipidana apabila melakukan tindak pidana korupsi.

Kata kunci: Pertanggungjawaban Pidana Korporasi, Korupsi, Pengadaan Barang Dan Jasa
\end{abstract}


Jurnal Magister Hukum Program Pascasarjana Universitas HKBP Nommensen

Volume 02 Nomor 02 Juli 2021 Halaman. 215-231 e-ISSN: 2723-164X p-ISSN: 2722-9858

http://ejournal.uhn.ac.id/index.php/opinion

\section{A. Pendahuluan}

Saat ini, kehadiran korporasi berperan penting dalam membantu perputaran perekonomian. Peningkatan modernisasi di dunia, mengakibatkan berkembangnya peran alatalat komunikasi, transportasi, teknologi dan sebagainya. Melalui peningkatan modernisasi tersebut, maka keberadaan korporasi menjadi sangat penting dikarenakan korporasi banyak berperandalam kegiatan ekonomi, seperti penyediaan lapangan pekerjaan, menghasilkan barang produksi yang bertujan untuk memenuhi kebutuhan masyarakat banyak, sekaligus juga memberikan pengaruh bagi pendapatan maupun pengeluaran negara.

Selain peranan yang dimiliki oleh korporasi dalam membantu perputaran perekonomian, dalam melakukan perannya tersebut, sering sekali korporasi melakukan kejahatan, salah satunya ialah tindak pidana korupsi. Tujuan korporasi melakukan tindak pidana korupsi adalah dalam rangka mengejar keuntungan yang sebanyak-banyaknya. Keberadaan korporasi sebagai pelaku tindak pidana belum diakui oleh KUHP. Akan tetapi secara umum, ketentuan di luar KUHP seperti tindak pidana korupsi telah mengakui korporasi sebagai pelaku tindak pidana korupsi.

Korporasi sebagai subjek hukum pidana di kalangan para sarjana menimbulkan pro dan kontra. Alasan yang kontra karena korporasi tidak mungkin melakukan tindak pidana sehingga tidak mungkin memiliki kesalahan(mensrea). ${ }^{1}$ Karena di dalam hukum pidana terdapat asas Geen Straf Zonder Schul, yang artinya tiada pidana tanpa kesalahan. Asas ini tidak menghendaki dipidananya seseorang yang terbukti melakukan pelanggaran tetapi tanpa adanya kesalahan. ${ }^{2}$

Sedangkan yang pro berpendapat bahwa dengan diberlakukannya pertanggungjawaban pidana korporasi ini akan meningkatkan kualitas kinerja perusahana, akan mengontrol kinerja orang-orang yang ada di dalam korporasi, dan mengurangi kerugian yang ditimbulkan oleh korporasi. Tanpa adanya tanggungjawab pidana korporasi, korporasi akan lari dari tuntutan moral atas pelanggaran yang dilakukannya. ${ }^{3}$

Tindak pidana korporasi atau kejahatan korporasi adalah tindak pidana yang dilakukan oleh orang-orang yang ada di dalam korporasi, yang kesemuanya bertujuan untuk memberikan keuntungan bagi korporasi. Dalam pemberian pengertian kejahatan korporasi ini, David O. Friedrichs berpendapat bahwa kejahatan korporasi adalah tindak pidana yang dilakukan oleh pengurus korporasi untuk kepentingan korporasi atau tindak pidana yang dilakukan oleh korporasi itu sendiri. ${ }^{4}$

Undang-undang Nomor 31 Tahun 1999 jo Undang-undang Nomor 20 Tahun 2001, yaitu Pasal 20 mengatur korporasi sebagai pelaku tindak pidana korupsi, diantaranya:

1. Dalam hal tindak pidana korupsi dilakukan oleh atau atas nama suatu korporasi, maka tuntutan dan penjatuhan pidana dapat dilakukan terhadap korporasi dan atau pengurusnya.

2. Tindak pidana korupsi dilakukan oleh korporasi apabila tindak pidana tersebut dilakukan oleh orang-orang baik berdasarkan hubungan kerja maupun berdasarkan hubungan lain, bertindak dalam lingkungan korporasi tersebut baik sendiri maupun bersama-sama.

3. Dalam hal tuntutan pidana dilakukan terhadap suatu korporasi, maka korporasi tersebut diwakili oleh pengurus.

\footnotetext{
${ }^{1}$ Sutan Remy Sjahdeini, Ajaran Pemidanaan: Tindak Pidana korporasi E Seluk-beluknya, (Jakarta: Kencana, 2017), hal. 50 .

${ }^{2}$ Muladi dan Dwidya Priyatno, Pertanggungjawaban Pidana Korporasi, (Jakarta: Kencana, 2010), hal. 99.

${ }^{3}$ Mahrus Ali, Asas-asas Hukum Pidana Korporasi, (Jakarta: Rajawali Pers, 2018), hal. 103.

${ }^{4}$ Ibid., hal. 9 .
} 
4. Pengurus yang mewakili korporasi sebagaimana dimaksud dalam ayat (3) dapat diwakili oleh orang lain.

5. Hakim dapat memerintahkan supaya pengurus korporasi menghadap sendiri di pengadilan dan dapat pula memerintahkan supaya pengurus tersebut dibawa ke sidang pengadilan.

6. Dalam hal tuntutan pidana dilakukan terhadap korporasi, maka panggilan untuk menghadap dan penyerahan surat panggilan tersebut disampaikan kepada pengurus di tempat tinggal pengurus atau di tempat pengurus berkantor.

7. Pidana pokok yang dapat dijatuhkan terhadap korporasi hanya pidana denda, dengan ketentuan maksimum pidana ditambah $1 / 3$ (satu pertiga).

Undang-undang tindak pidana korupsi mengatur berbagai jenis tindak pidana korupsi, salah satunya ialah pengadaan barang dan jasa dalam bentuk kolusi. Pasal 1 ayat (4) Undangundang Republik Indonesia Nomor 28 Tahun 1999 tentang Penyelenggaraan Negara yang Bersih dan Bebas dari Korupsi, Kolusi dan Nepotisme, menyatakan bahwa kolusi adalah permufakatan atau kerjasama secara melawan hukum antar-Penyelenggara Negara atau antara Penyelenggara Negara dan pihak lain yang merugikan orang lain, masyarakat dan atau negara. Kata kolusi berasal dari bahasa Inggris "collution" yang berarti kerja sama rahasia untuk maksud yang tidak terpuji; atau persekongkolan. ${ }^{5}$ Menurut Teten Masduki, koordinator ICW (Indonesia Corruption Watch) periode 1998-2008, kolusi adalah sarana atau cara untuk melakukan tindak pidana korupsi. ${ }^{6}$ Salah satu contoh yang dapat dilihat atas pernyataan Teten Masduki tersebut ialah PT.DGI yang telah terbukti secara sah dan meyakinkan melakukan tindak pidana korupsi, dalam Putusan Nomor 81/Pid.Sus/Tipikor/2018/PN.Jkt.Pst, yang merupakan hasil dari persekongkolan PT.DGI dengan beberapa korporasi, baik swasta maupun milik negara.

Sebagai subjek hukum pidana, korporasi tersebut dapat dimintakan pertanggungjawaban pidananya sebagaimana diatur di dalam undang-undang tindak pidana korupsi. Namun pertanggungjawaban pidana ini dapat dimintakan apabila atas perbuatannya tersebut ditemukan adanya unsur kesalahan. Sebab suatu tindak pidana tidak lepas dari dua unsur, yaitu adanya perbuatan yang melanggar ketentuan undang-undang (actus reus) dan adanya kesalahan (mens rea). ${ }^{7}$

Namun jika melihat salah satu teori pertanggungjawaban pidana korporasi, yaitu teori strict liability mengatakan bahwa pertanggungjawaban pidana korporasi dapat dimintakan tanpa adanya unsur kesalahan. ${ }^{8}$ Dalam hal ini, L.B. Curzon mengemukakan tiga alasan mengapa unsur kesalahan tidak perlu dibuktikan di dalam strict liability. Pertama, sangat esensial untuk menjamin agar dipatuhi peraturan tertentu yang diperlukan untuk kesejahteraan masyarakat. Kedua, akan sulit membuktikan adanya kesalahan atas pelanggaran yang berhubungan dengan kesejahteraan masyarakat. Ketiga, tingginya bahaya sosial yang ditimbulkan oleh korporasi. ${ }^{9}$

\section{B. Metode Penelitian}

Metodologi penelitian adalah ilmu yang memperlajari cara-cara melakukan pengamatan dengan pemikiran yang tepat secara terpadu melalui tahapan-tahapan yang disusun secara

\footnotetext{
${ }^{5}$ Huzaemah T.Yanggo, "Korupsi, Kolusi, Nepotisme dan Suap (KKNS) Dalam Pandangan Hukum Islam". Tahkim. Vol. IX No.1, Juni 2013, hal. 2.

${ }^{6}$ Ibid., hal. 3 .

${ }^{7}$ Hasbullah F. Sjawie, Pertanggungjawaban Pidana Korporasi pada Tindak Pidana Korupsi, (Depok: Prenadamedia Group, 2018), hal. 10.

${ }^{8}$ Mahrus Ali, Op.Cit., hal. 112.

${ }^{9}$ Ibid., hal. 113-114.
} 
ilmiah untuk mencari serta menganalisis dan menyimpulkan untuk dapat diperoleh suatu kebenaran. Di dalam metodologi penelitian ini terdapat ruang lingkup penelitian. Ruang lingkup adalah batasan banyaknya cakupan dalam sebuah masalah, baik dalam bentuk materi, variable yang diteliti, subjek, dan sebagainya. ${ }^{10}$ Adapun ruang lingkup dalam penelitian ini ialah sebatas untuk mengetahui dan menganalisis dua hal berikut: Bentuk pertanggungjawaban pidana korporasi di dalam Undang-undang tindak pidana korupsi. Pertanggungjawaban pidana korporasi yang melakukan tindak pidana korupsi dalam pengadaan barang dan jasa (Studi Putusan Nomor 81/Pid.Sus/Tipikor/2018/PN.Jkt.Pst.

\section{Pembahasan}

Bentuk Pertanggungjawaban Pidana Korporasi Di Dalam Undang-Undang Nomor 31 Tahun 1999 Jo Undang-Undang Nomor 20 Tahun 2001 Tentang Tindak Pidana Korupsi

Pasal 20 Undang-Undang Nomor 31 Tahun 1999 jo Undang-Undang Nomor 20 Tahun 2001 tentang Pemberantasan Tindak Pidana Korupsi, mengatur tentang pertanggungjawaban pidana korporasi, yang bunyinya:

1. Dalam hal tindak pidana korupsi dilakukan oleh atau atas nama suatu korporasi, maka tuntutan dan penjatuhan pidana dapat dilakukan terhadap korporasi dan/atau pengurusnya.

2. Tindak pidana korupsi dilakukan oleh korporasi apabil tindak pidana tersebut dilakukan oleh orang-orang baik berdasarkan hubungan kerja maupun berdasarkan hubungan lain, bertindak dalam lingkungan korporasi tersebut baik sendiri maupun bersama-sama.

3. Dalam hal tuntutan pidana dilakukan terhadap suatu korporasi, maka korporasi tersebut diwakili oleh pengurus.

4. Pengurus yang mewakili korporasi sebagaimana dimaksud dalam ayat (3) dapat diwakili oleh orang lain.

5. Hakim dapat memerintahkan supaya pengurus korporasi menghadap sendiri di pengadilan dan dapat pula memerintahkan supaya pengurus tersebut dibawa ke sidang pengadilan.

6. Dalam hal tuntutan pidana dilakukan terhadap korporasi, maka panggilan untuk menghadap dan penyerahan surat panggilan tersebut disampaikan kepada pengurus di tempat tinggal pengurus atau di tempat pengurus berkantor.

7. Pidana pokok yang dapat dijatuhkan terhadap korporasi hanya pidana dengan denda, dengan ketentuan maksimum pidana ditambah $1 / 3$ (satu pertiga).

Dari bunyi Pasal 20 di atas, dapat diketahui bahwa korporasi merupakan salah satu subjek hukum pidana yang diakui di dalam Undang-Undang Tindak Pidana Korupsi. Diakuinya korporasi sebagai subjek hukum pidana di dalam Undang-Undang Tindak Pidana Korupsi artinya bahwa Undang-Undang Tindak Pidana Korupsi memberikan kemungkinan untuk meminta pertanggungjawaban pidana kepada korporasi.

Namun pertanggungjawaban pidana ini dapat dimintakan kepada korporasi hanya apabila tindak pidana tersebut dilakukan oleh orang-orang "yang memiliki hubungan kerja" atau "memiliki hubungan lain" dan tindak pidana tersebut harus dilakukan "dalam lingkungan korporasi tersebut," sebagaimana diatur di dalam Pasal 20 ayat 2 (dua). Apa yang dimaksud dengan "orang-orang yang memiliki hubungan kerja atau hubungan lain, serta bertindak dalam lingkungan korporasi" tidak ada dijelaskan di dalam Undang-Undang Tindak Pidana Korupsi. Oleh sebab itu, untuk mengetahui maksud dari frasa tersebut harus dilakukan penafsiran hukum.

1o Pelayanan Publik.id, "Pengertian Ruang Lingkup, Manfaat dan contohnya", (https:/www.google.com/amp/s/pelayananpublik.id/2019/o9/12/pengertian-ruang-lingkup-manfaat-dancontohnya/amp/), diakses pada 17 Maret 2020, Pukul 11.58 WIB. 
http://ejournal.uhn.ac.id/index.php/opinion

Menurut Sutan Remy Sjahdeini, yang dimaksud dengan "orang-orang yang memiliki hubungan kerja" adalah orang-orang yang memiliki hubungan kerja sebagai pengurus atau sebagai pegawai, yaitu:

1) Berdasarkan anggaran dasar dan perubahannya,

2) Berdasarkan pengangkatan sebagai pegawai dan perjanjian kerja dengan korporasi,

3) Berdasarkan surat pengangkatan sebagai pegawai, atau

4) Berdasarkan perjanjian kerja sebagai pegawai.

Sedangkan yang dimaksud dengan "orang-orang berdasarkan hubungan lain" adalah orang-orang yang memiliki hubungan lain dengan korporasi selain hubungan kerja. Orangorang berdasarkan hubungan lain ini mewakili korporasi mewakili korporasi untuk melakukan perbuatan hukum untuk dan atas nama korporasi berdasarkan:

1) Pemberian kuasa,

2) Perjanjian dengan pemberian kuasa (pemberian kuasa bukan diberikan dengan surat kuasa tersendiri, tetapi dicantumkan dalam perjanjian itu sehingga merupakan bagian yang tidak terpisahkan dari perjanjian tersebut), atau

3) Pendelegasian wewenang.

Dengan demikian, apabila suatu tindak pidana korupsi dilakukan oleh orang-orang bukan berdasarkan "hubungan kerja atau hubungan lain" dan tidak dilakukan "di dalam lingkungan korporasi," maka perbuatan tersebut tidak dapat diatributkan sebagai perbuatan korporasi dan tidak dapat dibebankan pertanggungjawaban pidana kepada korporasi atas tindak pidana korupsi yang dilakukan oleh orang-orang tersebut.

Apabila dilakukan penuntutan terhadap korporasi akibat suatu tindak pidana korupsi yang terjadi, maka berdasarkan Pasal 20 ayat (6) Undang-Undang Pemberantasan Tindak Pidana Korupsi, surat panggilan untuk menghadap dan surat penyerahan panggilan diberikan kepada pengurus, hal ini sejalan dengan Pasal 20 ayat (3) dan ayat (4) Undang-Undang Pemberantasan Tindak Pidana Korupsi, yang menyatakan bahwa korporasi tersebut diwakili oleh pengurus yang kemudian dapat diwakili oleh orang lain. Namun pengurus tidak dapat diwakilkan oleh orang lain apabila Hakim berdasarkan kewenangannya memerintahkan supaya pengurus menghadap sendiri ke pengadilan atau dibawa ke pengadilan, sesuai dengan ketentuan Pasal 20 ayat (5) Undang-Undang Pemberantasan Tindak Pidana Korupsi.

Kemudian apabila korporasi telah selesai diadili dan dinyatakan bersalah, maka bentuk pertanggungjawaban pidana berupa pidana pokok yang dapat dijatuhkan kepada korporasi hanyalah pidana denda dengan ketentuan maksimum pidana ditambah 1/3 (satu pertiga). Hal ini dikarenakan koporasi tidak memiliki tubuh seperti orang perseorangan yang memungkinkan untuk diberikan pidana penjara atau kurungan.

Lalu pidana tambahan yang dapat diberikan sesuai dengan Pasal 18 Undang-Undang Nomor 31 Tahun 1999 jo Undang-Undang Nomor 20 Tahun 2001 tentang Pemberantasan Tindak Pidana Korupsi, berupa prampasan barang bergerak yang berwujud atau yang tidak berwujud atau barang yang tidak bergerak yang dibunakan untuk atau yang diperoleh dari tindak pidana korupsi, pembayaran uang pengganti, penutupan seluruh atau sebagian perusahaan, pencabutan seluruh atau sebagian hak-hak tertentu atau penghapusan seluruh atau sebagian keuntungan tertentu.

Pertanggungjawaban Pidana Korporasi Yang Melakukan Tindak Pidana Korupsi Pengadaan Barang Dan Jasa (Studi Kasus Putusan Nomor 81 / Pid.Sus / Tipikor / 2018 / Pn.Jkt.Pst.)

Pada sub Bab ini, penulis akan memaparkan dan menganalisis kasus berdasarkan Undang-undang atau peraturan terkait. Untuk memahami pertanggungjawaban pidana 
Jurnal Magister Hukum Program Pascasarjana Universitas HKBP Nommensen

Volume 02 Nomor o2 Juli 2021 Halaman. 215-231 e-ISSN: 2723-164X p-ISSN: 2722-9858

http://ejournal.uhn.ac.id/index.php/opinion

korporasi yang melakukan tindak pidana korupsi pengadaan barang dan jasa, penulis mengambil Putusan Nomor 81/Pid.Sus/Tipikor/2018/Pn.Jkt.Pst., sebagai bahan analisis.

1) Kasus Posisi

Identitas Terdakwa

Nama lengkap

: PT NUSA KONSTRUKSI ENJINIRING, Tbk

(Sebelumnya PT DUTA GRAHA INDAH, Tbk);

Tempat pendirian : Akta Notaris Maria Lidwina Indriani Soepojo,SH.,

/Nomor

Anggaran Dasar/Akta : Nomor 38 tanggal 11 Januari 1982;

pendirian

: Risalah Rapat Umum Pemegang Saham Luar Bias

PT Duta Graha Indah, Tbk Nomor o8 tanggal o9

Agustus 2020;

Tempat kedudukan : ITS Towe (Nifarro Park), lantai 21, Jalan Raya Pasar

Minggu km. 18, Jakarta Selatan;

Kebangsaan : Indonesia;

Jenis korporasi : Badan Hukum;

Bentuk kegiatan/usaha : General kontraktor;

No. Pokok Wajib Pajak : 01.370.350.9-054.0oo;

Diwakili oleh pengurus korporasi yang bertindak untuk dan atas nama terdakwa:

Nama lengkap : : Djoko Eko Suprastowo;

Tempat lahir : Bojonegoro;

Umur/tanggal lair : 62 tahun/15 Agustus 1956;

Jenis kelamin : Laki-laki;

Kebangsaan : Indonesia;

Alamat tinggal

: Jalan Merak 3 Blok F3 Nomor 18, Bintaro Jaya 1, Jakarta;

Alamat kantor $\quad: \quad$ PT Nusa Konstruksi Enjiniring, Tbk., Sunan Kalijagan Nomor 64, Blok M, Jakarta Selatan;

Agama : Islam;

Pekerjaan/jabatan : Direktur Utama PT Nusa Konstruksi Enjiniring, Tbk.;

Pendidikan Terakhir $\quad$ : S2;

Bahwa Dudung Purwadi merupakan Direktur Utama dari Terdakwa yang diangkat berdasarkan Akta Pernyataan Keputusan Rapat PT Duta Graha Indah, Tbk. Nomor 6 tanggal 8 Januari 2009 serta mempunyaitugas memimpin perusahaan dan menjalankan rencana kerja dan anggaran perusahaan (RKAP) yang bergerak di bidang usaha jasa konstruksi. Dalam menjalankan tugasnya, Dudung Purwadi dibantu oleh beberapa direksi antara lain Johanes Adi Widodo (Wakil Direktur Utama merangkap Direktur Marketing I) dan Laurentius Teguh Khasanto Tan (Direktur Keuangan); Sekitar awal tahun 2009 bertempat di kantor Anugerah Grup, untuk kepentingan Terdakwa, Dudung Purwadi menghadiri pertemuan atas undangan Muhammad Nazarudin (selaku pemilik/ pengendali Anugerah Grup), yang dihadiri juga oleh perwakilan beberapa badan usaha milik negara (BUMN) yang bergerak di bidang konstruksi diantaranya PT Adhi Karya, PT Pembangunan Perumahan, PT Waskita Karya, dan PT Nindya Karya. Dalam pertemuan tersebut, Muhammad Nazarudin menyampaikan bahwa Anugerah Grup sedang berupaya mendapatkan anggaran untuk beberapa proyek konstruksi di DPR gunadibagikan kepada perusahaanperusahaan yang hadir, untuk itu meminta BUMN dan Terdakwanantinya saling membantu dalam proses pelelangan, yakni apabila salah satu perusahaan telah diarahkan menjadi pemenang lelang maka perusahaan lainnya harus 
http://ejournal.uhn.ac.id/index.php/opinion

bersedia menjadi pendamping lelang, dan demikian sebaliknya. Pertemuan tersebut merupakan tindak lanjut dari pertemuan antara Dudung Purwadi yang didampingi Mohammad El Idris (Manajer Marketing dari Terdakwa) dengan Muhammad Nazarudin diakhir tahun 2008, dimana saat itu Dudung Purwadi meminta Muhammad Nazarudin agar Terdakwa dapat diberikan pekerjaan proyek pemerintah T.A. 2009 dan untuk itu bersedia memberikan sejumlah fee kepada Muhammad Nazarudin; Menindaklanjuti kesepakatan itu, Mohammad El Idris menemui Mindo Rosalina Manulang di kantor Anugerah Grup. Dalam pertemuan tersebut, Mindo Rosalina Manulang menyampaikan bahwa pihak Anugerah Grup yang akan mengatur proses lelangnya dan Terdakwa harus menyerahkan fee sebesar $15 \%$ dari nilai real cost kontrak.Mohamad El Idris lalumelaporkan permintaan fee ini kepada Dudung Purwadi dan Dudung Purwadi menyetujuinya;

Pada tanggal 29 Mei 2009 panitia lelang melakukan pengumuman lelang pekerjaan Pengadaan Sarana dan Prasarana Pendidikan Khusus Penyakit Infeksi dan Pariwisata T.A. 2009 dengan metode prakualifikasi dan pagu anggaran sejumlah Rp.55.000.00o.ooo,oo (lima puluh lima miliar rupiah) berdasarkan surat nomor 07.29/ H14.11/ LK/ V/ 2009 pada surat kabar Media Indonesia. Pada lelang tersebut, Made Meregawa selaku pejabat pembuat komitmen (PPK) dan panitia lelang mempergunakan harga perkiraan sendiri (HPS) atau owner estimate (OE) yang dibuat oleh Konsultan Perencana PT Arkitek Team Empat (kenalan dari Mohamad El Idris). Rincian HPS tersebut juga diberikan kepada Terdakwa dan telah digunakan untuk membuat angka penawaran yang harganya mendekati pagu anggaran, yang mana besaran angka penawaran telah disetujui Dudung Purwadi sebagaimana laporan berjenjang dari Wisnu Handono melalui Mohamad El Idris; Bahwa proses lelang kemudian diikuti oleh Terdakwa, PT Prambanan Dwipaka, PT Adhi Karya, PT Nindya Karya serta PT Pembangunan Perumahan, dan sebagaimana telah disepakati sebelumnya, maka Terdakwa kemudian ditetapkan sebagai pemenang lelang dengan alasan mengajukan penawaran paling rendah. Selanjutnya, pada tanggal 17 September 2009 bertempat di Kampus Universitas Udayana, Dudung Purwadi dan Made Meregawa menandatangani Surat Perjanjian (kontrak) Kerja Jasa Pemborongan Pekerjaan Pembangunan Rumah Sakit Pendidikan Khusus Penyakit Infeksi dan Pariwisata Universitas Udayana senilai Rp.46.745.000.ooo,oo; Bahwa atas pelaksanaan proyek dimaksud, Terdakwa telah menerima pembayaran sebesar $100 \%$ dengan jumlah keseluruhan Rp.41.220.590.909,00, dan menyatakan pekerjaan telah selesai 100\% berdasarkan pada Berita Acara Serah Terima Pekerjaan Nomor 03.10/ H14.11/ LK/ XII/ 2009 tanggal 30 Desember 2009 dan Berita Acara Serah Terima II Nomor 03.11/ H14.11/ VI/ 2010 tanggal 24 Juni 2010 yang ditandatangani oleh Dudung Purwadi dan Made Meregawa, padahal menurut hasil pemeriksaan ahli ITB pekerjaan baru terealisasi sebesar $67,03 \%$, sehingga terdapat kerugian keuangan negara sejumlah Rp.7.837.004.15o,81; Sebagaimana kesepakatan sebelumnya, maka setelah menerima pembayaran, Terdakwa pun memberikan fee kepada Muhammad Nazarudin melalui PT Anak Negeri sejumlah Rp.1.183.455.00o,oo, PT Anugerah Nusantara sejumlah Rp.2.681.60o.0oo,oo dan Grup Permai sejumlah Rp.5.409.389.00o,oo, dengan cara seolah-olah perusahaan-perusahaan tersebut merupakan subkon Terdakwa ataupun menerima pembayaran atas material yang dibeli Terdakwa;

Pada T.A. 2010, dianggarkan pekerjaan lanjutan (tahap II) Pembangunan Rumah Sakit Pendidikan Khusus Penyakit Infeksi dan Pariwisata Universitas Udayana senilai Rp.110.000.000.00o,oo (seratus sepuluh miliar rupiah). Untuk mendapatkan pekerjaan tersebut, Dudung Purwadi melalui Mohamad El Idris kembali melakukan pendekatan kepada Muhammad Nazarudin melalui Mindo Rosalina Manulang. Permintaan Dudung Purwadi dipenuhi oleh Muhammad Nazarudin dengan besaran fee tetap sebesar 15\%, yang mana keberadaan fee tersebut telah disetujui oleh Dudung Purwadi dikarenakan 
Jurnal Magister Hukum Program Pascasarjana Universitas HKBP Nommensen

Volume 02 Nomor 02 Juli 2021 Halaman. 215-231

e-ISSN: 2723-164X p-ISSN: 2722-9858

http://ejournal.uhn.ac.id/index.php/opinion

memperolehlaporan dari Mohamad El Idris; Bahwa dalam pelaksanaan lelang proyek Pembangunan Rumah Sakit Pendidikan Khusus Penyakit Infeksi dan Pariwisata Universitas Udayana(lanjutan) T.A. 2010, Made Meregawa dan panitia lelang kembali menggunakan HPS yang dibuat oleh Konsultan Perencana PT Arkitek Team Empat, dan rincian HPS dimaksud juga digunakan Terdakwa untuk membuat harga penawaran lelang dan telah disetujui Dudung Purwadi sebagaimana laporan berjenjang dari Wisnu Handono melalui Mohamad El Idris. Untuk memenangkan Terdakwa dalam lelang tersebut, Dudung Purwadi memerintahkan Wisnu Handono memantau proses lelang dan meminta agar nilai penawaran lebih rendah $5 \%$ dari pagu anggaran (termasuk PPn 10\%) sehingga berjumlah Rp.91.978.0oo.ooo,oo; Pada tanggal 21 September 2010, Terdakwa kembali ditetapkan sebagai pemenang lelang karena harga penawarannya paling rendah, dan pada tanggal 1 Oktober 2010 bertempat di Kampus Universitas Udayana, Dudung Purwadi dan Made Meregawa menandatangani Surat Perjanjian Kerja Jasa Pemborongan Pekerjaan Pembangunan Rumah Sakit Pendidikan KhususPenyakit Infeksi dan Pariwisata Universitas Udayana T.A. 2010 dengan nilai kontrak sejumlah Rp.91.978.000.000,oo;

Bahwa atas pelaksanaan proyek dimaksud, Terdakwa telah menerima pembayaran sebesar ${ }_{100 \%}$ dengan jumlah keseluruhan Rp.81.107.872.727,00, dan menyatakan pekerjaan telah selesai 100\% berdasarkan Berita Acara Serah Terima Pekerjaan Nomor 01.2/ UN.1A.11/ LK/ BAST/ 2010 tanggal 29 Desember 2010 dan Berita Acara Serah Terima II Nomor 03.11/ H.14.11/VI/ 2010 tanggal 24 Juni 2011 yang ditandatangani oleh Dudung Purwadi dan Made Meregawa, padahal menurut hasil pemeriksaan ahli ITB pekerjaan baru terealisasi sebesar 57,49\%, sehingga terdapat kerugian keuangan negara sejumlah Rp.18.116.780.429,76; Setelah Terdakwa menerima pembayaran, Terdakwa menyerahkan fee sejumlah Rp.1.o16.500.ooo,oo kepada Muhammad Nazarudin melalui Yulianis (bagian keuangan grup Permai) dalam bentuk cek BCA atas nama PT Bina Bangun Abadi; Bahwa rangkaian perbuatan Dudung Purwadi dan para pengurus Terdakwa lainnya tersebut telah memberikan keuntungan bagi Terdakwa sejumlah Rp.24.778.603.605,00 dengan rincian pada tahun 2009 sejumlah Rp.6.780.551.865,00 dan pada tahun 2010 sejumlah Rp.17.998.051.740,o0 yang mengakibatkan kerugian keuangan negara sejumlah Rp.25.953.784.580,57 sesuai dengan Laporan Hasil Audit Perhitungan Kerugian Negara atas Perkara Dugaan Tindak Pidana Korupsi dalam Pekerjaan Pembangunan Rumah Sakit Pendidikan Khusus Infeksi dan Pariwisata Universitas Udayana T.A. 2009-2010, dengan Nomor SR-698/ D6/ o1/ 2016 tanggal 4 Oktober 2016;

Bahwa selain menjadi penyedia barang/ jasa atas proyek Pembangunan Rumah Sakit Khusus Infeksi dan Pariwisata Universitas Udayana TahunAnggaran 2009 dan 2010 sebagaimana telah diuraikan di atas,dengan bantuan Muhammad Nazarudin, Terdakwa juga telah menjadi penyedia barang/ jasa atas beberapa proyek pembangunan lainnya, yaitu:

1. Proyek Gedung Wisma Atlet Jakabaring di Palembang, Provinsi Sumatera Selatan, dengan jumlah keuntungan Rp.42.717.417.289,oo;

2. Proyek Gedung Balai Pendidikan dan Pelatihan Ilmu Pelayaran (BP2IP) Surabaya, Provinsi Jawa Timur, dengan jumlah keuntungan Rp.44.536.582.667,00;

3. Proyek Gedung Rumah Sakit Pendidikan Universitas Mataram di Mataram, Provinsi Nusa Tenggara Barat, dengan jumlah keuntungan Rp.23.902.726.864,oo;

4. Proyek Gedung Rumah Sakit Umum Daerah (RSUD) Sungai Dareh di Kabupaten Dharmasraya, Provinsi Sumatera Barat, dengan jumlah keuntungan Rp.20.503.587.805,00;

5. Proyek Gedung Cardiac di Rumah Sakit Adam Malik Medan, Provinsi Sumatera Utara, dengan jumlah keuntungan Rp.4.015.460.587,oo; 
6. Proyek Paviliun di Rumah Sakit Adam Malik Medan, Provinsi Sumatera Utara, dengan jumlah keuntungan Rp.2.164.903.874,00;

7. Proyek Rumah Sakit Tropis Universitas Airlangga, di Surabaya, Provinsi Jawa Timur

\section{2) Dakwaan}

Tahun Anggaran 2009 dan 2010, dengan jumlah keuntungan Rp.77.478.850.619,00;

Berdasarkan kronologis kasus yang diuraikan di atas, terdakwa diperhadapkan ke persidangan dengan dakwaan yang diberikan oleh penuntut umum berupa dakwaan alternatif, yaitu:

Pertama :

Pasal 2 ayat (1) jo Pasal 18 Undang-undang Republik Indonesia Nomor 31 Tahun 1999 tentang Pemberantasan Tindak Pidana Korupsi sebagaimana telah diubah dengan Undang-undang Republik Indonesia Nomor 20 Tahun 2001 tentang Perubahan Atas Undang-undang Republik Indonesia Nomor 31 Tahun 1999 tentang Pemberantasan Tindak Pidana Korupsi jo Pasal 55 ayat (1) ke-1 dan Pasal 64 ayat (1) Kitab Undang-undang Hukum Pidana.

Atau,

Kedua:

Pasal 3 jo Pasal 18 Undang-undang Republik Indonesia Nomor 31 Tahun 1999 tentang Pemberantasan Tindak Pidana Korupsi sebagaimana telah diubah dengan Undang-undang Republik Indonesia Nomor 20 Tahun 2001 tentang Perubahan Atas Undang-undang Republik Indonesia Nomor 31 Tahun 1999 tentang Pemberantasan Tindak Pidana Korupsi jo Pasal 55 ayat (1) ke-1 dan Pasal 64 ayat (1) Kitab Undang-undang Hukum Pidana.

\section{3) Tuntutan}

Tuntutan Jaksa Penuntut Umum terhadap terdakwa pada pokoknya memohon supaya majelis memutuskan sebagai berikut:

1. Menyatakan PT Nusa Konstruksi Enjinirin, Tbk (sebelumnya bernama PT Duta Graha Indah, Tbk) terbukti secara sah dan meyakinkan bersalah melakukan tindak pidana korupsi sebagaimana dalam dakwaan pertama melanggar Pasal 2 ayat (1) jo Pasal 18 Undang-undang Republik Indonesia Nomor 31 Tahun 1999 tentang Pemberantasan Tindak Pidana Korupsi sebagaimana telah diubah dengan Undang-undang Republik Indonesia Nomor 20 Tahun 2001 tentang Perubahan atas Undang-undang Nomor 31 Tahun 1999 tentang Pemberantasan Tindak Pidana Korupsi jo Pasal 55 ayat (1) ke-1 dan Pasal 64 ayat (1) Kitab Undang-undang Hukum Pidana;

2. Menjatuhkan pidana terhadap terdakwa dengan pidana denda sejumlah Rp.1.00o.ooo.ooo,oo (satu miliar rupiah). Jika dalam jangka waktu satu bulan sejak putusan pengadilan berkekuatan hukum tetap terdakwa tidak membayar denda dimaksud, maka harta bendanya disita oleh jakda dan dilelang untuk menutupi denda tersebut dan jangka waktu satu bulan dimaksud dapat diperpanjang selama satu bulan hanya dengan alasan kuat;

3. Menjatuhkan pidana tambahan terhadap terdakwa untuk membayar uang pengganti sejumlah Rp.188.732.756.416,oo (seratus delapan pulunh delapan miliar tujuh ratus tiga puluh dua juta tujuh ratus lima puluh enam ribu empat ratus enam belas rupiah) selambat-lambatnya satu bulan setelah putusan pengadilan berkekuatan hukum tetap. Jika dalam jangka waktu tersebut Terdakwa tidak membayar uang pengganti maka harta bendanya disita oleh Jaksa dan dilelang untuk menutupi uang pengganti tersebut;

4. Menjatuhkan pidana tambahan berupa mencabut hak Terdakwa untuki mengikuti lelang proyek pemerintah selama 2 (dua) tahun yang selanjutnya dalam Replik Jaksa Penuntut Umum menjadi mencabut hak Terdakwa untuk mengikuti lelang pengadaan barang/jasa pemerintah selama 1 (satu) tahun; 
5. Menetapkan agar barang bukti:

Nomor 1 sampai 357 terlampir dalam berkas perkara; nomor 356 sampai dengan 357 dirampas untuk Negara sebagai pembayaran uang pengganti;

6. Menetapkan biaya perkara sebesar Rp.10.00o,oo (sepuluh ribu rupiah) dibebankan kepada Terdakwa.

\section{4) Dasar Pertimbangan Hakim}

Majelis Hakim mempertimbangkan beberapa hal, sebagai berikut:

1. Keterangan Saksi (Dudung Purwadi)

Tempat lahir di Surabaya, 64 tahun/10 Desember 1953, jenis kelamin laki-laki, kebangsaan/kewarganegaraan Indonesia, alamat Apartemen Dharmawangsa \#805 Jalan Dharmawangsa VIII Jakarta, agama Islam, pekerjaan Direktur Utama PT Duta Graha Indah, Tbk awal tahun 1999 sampai dengan pertengahan tahun 2012; Bahwa saksi pernah menajdi Direktur Utama PT DGI mulai tahun 2009 sampai dengan pertengahan 2012; Bahwa yang mengangkat saksi menjadi Direktur Utama adalah RUPS, hanya RUPS saja yang berwenang; Bahwa saksi menjabat sebagai Dirut, ada juga Direksi lain, yang pertama adalah wakil Dirut adalah Adi Widodo, kemudian Direktur Keuangan adalah Laurensius, kemudian Direktur Operasi adalah Karman Hadi, Direktur Marketing adalah Ongki Abdulrahman, Direktur Luar Negeri Sutiono Teguh, Direktur Kepatuhan perusahaan adalah Widodo; Bahwa, saksi kenal Muhammad El Idris, padawaktu itu adalah Direktur Marketing Bahwa, saksi pernah bertemu dengan Muhammad Nazarudin 3 (tiga) kali; Bahwa, pertemuan pertama pada awal tahun 2009 ketika saksi diangkat sebagai Direktur Utama, saksi diperkenalkan oleh Muhammad El Idris ke tempatnya Nazarudin di kantor Kasablanka, di kantornya di Gedung Permai Tebet, kemudian yang kedua pada pertengahan tahun 2010 pada bulan Agustus di Warung Buncit, kemudian yang ketiga awal tahun 2011 di Restoran Nippon Kan, tapi di situ tidak lama, tidak lebih dari 5 (lima) menit karena hanya say hallo saja, tidak ada pembicaraan sama sekali; Bahwa, untuk pertemuan awal 2009, yang hadir pada saat itu adalah saksi, El Idris, Nazarudin, satu lagi Rosa (Mindo Rosalina Manulang), (yang dibicarakan saat itu) tidak spesifik karena saksi dikenalkan oleh Muhammad El Idris kemudian waktu itu saksi membawa company profile, dan saksi menjelaskan bahwasanya saksi dari PT DGI memperkenalkan diri kepada seluruh stakeholder, Pak Menteri, semualah Stakeholder, jasa konstruksi datang semua. Tugas saksi sebagai Dirut adalah memperkenalkan perusahaan saksi adalah perusahaan yang bagus yang mempunyai kemampuan untuk mengerjakan, karena selama ini saksi berpikiran hanya BUMN saja yang diperhatikan oleh Stakeholder, pokoknya yang paling bagus hanya BUMN, maka saksi berusaha meyakinkan Stakeholder bahwasanya perusahaan saksi adalah perusahaan yang bonafit dan punya kemampuan yang paling tidak setara dengan BUMN;

Bahwa, waktu itu Nazarudin tidak spesifik mengatakan (untuk nantinya dibantu apabila mendapatkan proyek dari Nazarudin), tapi sudah merupakan suatu kebiasaan kalau namanya diberi pasti ada rasa terima kasih, sempat Nazarudin mengatakan "Ini proyek nggak gratis", setahu saksi pasti tidak gratis karena Nazarudin yang mengurus, Nazarudin yang mengurus pastiada uangnya, karena Nazarudin berbicara seperti itu, saksi anggap itu sesuatu yang wajar; Bahwa, pada pertemuan kedua yang hadir adalah saksi dan M. El Idris, ada juga Nazarudin, tujuan utama saksi datang kalau tidak salah bulan Juli atau Agustus 2010, saksi mendengar Demokrat akan membangun kantor Pusat yang besar di daerah Pasar Minggu, kalau tidak salah di tanahnya milik Nazarudin, saksi melihat ini adalah peluang untuk mempromosikan PT DGI; Bahwa, sebelum menjabat sebagai Dirut (PT DGI), jabatan saksi adalah Kepala Cabang Surabaya, Jawa Timur;

Bahwa, pada tahun 2009, dua tahun setelah Tbk., saksi diminta untuk ke Jakarta dan saksi diikutkan fit and proper test oleh Komisaris, saksi tidak tahu siapa calon lainnya, tapi 
akhirnya saksi ditunjuk sebagai Dirut, walaupun tidak ada perubahan dari Direksi yang lain, hanya satusatunya yang diganti adalah Dirutnya; Bahwa, pada waktu itu terealisasi (permintaan proyek dari PT DGI kepada Nazarudin), termasuk juga Proyek yang di laksanakan Universitas Udayana (Unud) Denpasar Bali; Bahwa, saksi tahu proyek yang di Universitas Udayana adalah proyek yang diberikan oleh Nazarudin adalah dari M. El Idris, karena yang membawa adalah El Idris jadi semua tahu pasti dari Nazarudin; Bahwa, marketing saksi banyak, tidak hanya M. El Idris, jadi masingmasing punya bagian, artinya tugas M. El Idris adalah untuk mendapat proyek yang berasal dari Nazarudin, walaupun juga ada proyek-proyek lain, tetapi saksi tidak ingat yang dibawa oleh M. El Idris; Bahwa, pada tahun 2009, PT DGI juga mengerjakan proyek-proyek lain, swasta juga banyak, di Padang ada, di Makassar ada; Bahwa, untuk DGI cabang Surabaya ada juga proyek lain yang dikerjakan yang tidak berasal oleh Nazarudin; Bahwa, saksi tidak tahu terkait proses pelelangan di proyek Universitas Udayana tahun 2009 karena itu sudah merupakan tugas dari cabang, kalau dari wilayah Timur adalah dari cabang, jadi saksi tidak pernah diberi laporan dan bagi saksi, kalau tidak ada laporan berarti semua berjalan dengan lancar, yang dimaksud tugas dari cabang adalah benar tugas dari Wisnu Handono; Bahwa, saksi menandatangani dokumen terkait proyek rumah sakit Universitas Udayana) tetapi di dalam menyusun anggaran saksi tidak tanda tangan), dokumen yang saksi tanda tangani hanya terkait proyek rumah sakit Universitas Udayana) adalah dokumen kontrak; Bahwa, yang menyusun kontrak terkait proyek rumah sakit Universitas Udayana setahu saksi adalah (PT DGI) Cabang Surabaya; Bahwa, mengenai nilai kontrak proyek rumah sakit Universitas Udayana saksi lupa, yang kedua mungkin 10o-an miliar rupiah yang pertama mungkin 7o-an miliar rupiah; Bahwa, saksi tidak pernah dilibatkan dalam penyusunan harga penawaran dan tidak ada laporan, karena mekanismenya dari cabang laporan kemarketing-nya langsung ke Jakarta, kemudian operasional Surabaya melaporkan ke Direktur Operasi di Jakarta, jadi memang tidak direct ke saksi, kalau undirect biasanya ada rapat direksi, dalam rapat direksi biasanya disampaikan tentang proyek,progres proyeknya, dalam satu tahun kira-kira PT DGI ada 40-50 proyek, jadi spesifik saja pihak Nazarudin jadi laporan umum, tidak detail, semua secara umum; Bahwa, artinya memang ada pemberian fee kepada pihak Nazarudin, karena memang begitu saksi diminta oleh M. El Idris kemudian dicek oleh cost control dan dananya ada, ya sudah dia bisa mengeluarkan, itu sudah memang SOPnya demikian, saksi percaya dengan M. El Idris karena dia adalah bekas Dirut saksi pada saat saksi diangkat menjadi Kepala Cabang, M. El Idris adalah Dirut saksi, atasan saksi, mantan atasan saksi, oleh karena itu hubungan saksi ini sangat dekat dan percaya pada M. El Idris; Bahwa, kalau terkait dananya ada atau tidak itu saksi tidak tahu, tentunya policy saksi adalah selama cash flow nya ada dan positif dan itu masih sesuai dalam range budget-nya, ya silakan saja, ini cash flow atas masing-masing proyek tersebut; Bahwa, benar pendanaan pemberian fee tersebut hanya akan dibatasi dari uang masuk daripada proyek tersebut, benar uang fee bersumber dari pembayaran atas pelaksanaan proyek;

Bahwa, benar PT DGI telah memperoleh pembayaran seluruhnya atas pelaksanaan proyek tahun 2009; Bahwa, terkait apakah saksi pernah menandatangani Berita Acara Serah Terima (BAST)pada tahun 2009, berita acara kadang-kadang ada kadang dipalsukan, jadi saksi rasanya tidak pernah menandatangani surat, yang saksi tahu semuanya pasti sudah berjalan dengan acuan, hanya kadang-kadang karena mungkin bisa saja pada saat berita acara itu harus ditandatangani, saksi tidak berada di tempat, kalau harusmenunggu saksi datang bisa sajatidak terbayar karena semua ini crash program, semuanya adalah APBN-P karena waktunya hanya 3 bulan, 3,5 bulan, seperti Rp.1oo miliar itu kita selesaikan dalam waktu 3,5 bulan, sangat luar biasa crash program-nya, sehingga bisa selesai juga syukur Alhamdulillah, hanya memang adminsitrasi sudah saksi katakan kalau pas saksi keluar negeri ya seperti itulah kira-kira; 
Bahwa, saksi secara eksplisit tidak (mengizinkan dipalsukan tanda tangan saksi), cuma itu adalah common practice di (PT DGI), sejak dulu sebelum saksi (menjadi Dirut) kalau memang tidak ada Dirutnya memang harus dilakukan, karena daripada hangus; Bahwa, untuk tahun 2010, PT DGI mendapat proyek lanjutan di Universitas Udayana, nilai kontraknya sekitar 100an miliar rupiah, saksi juga yang menandatangani kontrak dengan Made Maregawa dari Universitas Udayana, tapi saksi tekankan di sini saksi tidak pernah bertemu dengan Made Maregawa, jadi prosesnya adalah ada satu dokumen di atas meja saksi, ya saksi lihat dan halaman pertama pada kontrak setelah ada paraf-paraf semua, saksi tanda tangani karena sudah ada paraf dari Direksi yang lain; Bahwa, PT DGI atas pelaksanaan proyek RS Universitas Udayana 2010) sudah mendapatkan pembayaran $100 \%$ dan betul sudah dibuat berita acara serah terimanya; Bahwa, benar atas pelaksanaan proyek RS Universitas Udayana 2010, PT DGI juga memberikan fee kepada pihak Nazarudin, saksi tidak tahu jumlahnya, saksi juga tidak tahu jumlah keuntungan yang diperoleh PT DGI dari pelaksanaan proyek RS Universitas Udayana 2010; Bahwa, selain atas proyek RS Universitas Udayana 2009 dan 2010) seingat saksi proyek yang diberikan oleh Nazarudin urut dari timur dulu yaitu adalah proyek RS Universitas Mataram, RS Universitas Udayana, RS Tropis di Surabaya, BP2IP Surabaya, Ponorogo, ke arah Sumatra Selatan proyek wisma atlet, kemudian ke arah Sumatra Barat itu proyek RSUD Sungai Dareh, kemudian di Jambi Universitas Jambi, kemudian di Medan ada 2 yaitu RS Adam Malik;

Bahwa, Komisaris tidak pernah bertanya apakah semua proyek yang diperoleh telah sesuai aturan atau tidak, karena memang sudah SOPnya demikian dan mestinya mereka percaya bahwa itu sesuai dengan SOP; Bahwa, Komisaris memiliki tugas untuk mengawasi jalannya Perusahaan Keterangan Terdakwa

\section{5) Putusan}

Berdasarkan beberapa hal yang telah dipertimbangkan, maka majelis hakim memutuskan sebagai berikut:

1. Terdakwa PT Nusa Konstruksi Enjiniring, Tbk., (sebelumnya bernama PT Duta Graha Indah, Tbk.), terbukti secara sah dan meyakinkan bersalah melakukan tindak pidana koupsi secara bersama-sama dan berlanjut, sebagaimana dalam dakwaan pertama;

2. Menjatuhkan pidana kepada Terdakwa oleh karena itu dengan pidana denda sejumlah Rp. 700.000.00o,oo (tujuh ratus juta rupiah), dengan ketentuan apabila pidana denda tersebut tidak dibayar paling lambat 1 (satu) bulan setelah putusan pengadilan berkekuatan hukum tetap, maka harta bendanya disita oleh jaksa dan dilelang untuk menutupi denda tersebut dan jangka waktu 1 (satu) bulan tersebut dapat diperpanjang selama 1 (satu) bulan hanya dengan alasan kuat;

3. Menjatuhkan pidana tambahan kepada Terdakwa untuk membayar uang pengganti sejumlah Rp.85.490.234.737,oo (delapan puluh lima miliar empat ratus sembilan puluh juta dua ratus tiga puluh empat ribu tujuh ratus tiga puluh tujuh rupiah) dengan ketentuan apabila uang pengganti tersebut tidak dibayar dalam waktu 1 (satu) bulan sesudah putusan pengadilan memperoleh kekuatan hukum tetap, maka harta bendanya dapat disita oleh Jaksa dan dilelang untuk menutupi uang pengganti tersebut;

4. Menjatuhkan pidana tamahan berupa mencabut hak Terdakwa untuk mengikuti lelang proyek pemerintah selama 6 (enam) bulan;

5. Barang bukti dirampas untuk negara, dan diperhitungkan sebagai pembayaran uang pengganti;

6. Membebankan biaya perkara kepada Terdakwa sebesar Rp.10.ooo,oo (sepuluh ribu rupiah). 
Jurnal Magister Hukum Program Pascasarjana Universitas HKBP Nommensen

Volume 02 Nomor 02 Juli 2021 Halaman. 215-231 e-ISSN: 2723-164X p-ISSN: 2722-9858

http://ejournal.uhn.ac.id/index.php/opinion

\section{6) Analisis Kasus}

Pertanggungjawaban pidana korporasi yang melakukan korupsi pengadaan barang dan jasa studi putusan nomor 81/Pid.Sus/Tipikor/2018/Pn.Jkt.Pst.

\section{A. Analisis Dakwaan}

Dakwaaan adalah tuntutan perkara yang diberikan oleh Jaksa Penuntut Umum dalam bentuk surat dakwaan. Sesuai dengan ketentuan Pasal 143 ayat (1) KUHAP, untuk mengadili suatu perkara, Penuntut umum wajib mengajukan permintaan disertai dengan surat dakwaan. Di dalam Surat Edaran Jaksa Agung Republik Indonesia Nomor: SE-004/J.A/11/1993, terdapat beberapa bentuk surat dakwaan, yaitu:

a. Dakwaan tunggal, yaitu surat dakwaan yang hanya memuat satu tindak pidana saja yang didakwakan, karena tidak adanya kemungkinan untuk mendakwakan dakwaan alternatif atau dakwaan pengganti lainnya.

b. Dakwaan alternatif, yaitu surat dakwaan yang membuat beberapa dakwaan yang disusun secara berlapis. Lapisan yang satu merupakan alternatif dan bersifat mengecualikan terhadap lapisan lainnya. Bentuk dakwaan ini digunakan bila belum didapat kepastian tentang tindak pidana mana yang paling tepat dapat dibuktikan. Dalam surat dakwaan alternatif ini, hanya satu dakwaan saja yang akan dibuktikan.

c. Dakwaan subsidair, yaitu surat dakwaan yang terdiri dari beberapa lapisan dakwaan. Maksud dari beberapa lapisan dakwaan ini ialah lapisan yang satu berfungsi sebagai penganti lapisan sebelumnya. Sistematik lapisan disusun secara berurut, dimulai dari tindak pidana yang diancam dengan pidana tertinggi sampai dengan tindak pidana yang diancam dengan pidana terendah. Dan pembuktiannya dilakukan secara berurut dimulai dari lapisan teratas sampai dengan lapisan yang dipandang terbukti.

d. Dakwaan kumulatif, yaitu surat dakwaan yang memuat beberapa dakwaan sekaligus dan harus dibuktikan satu demi satu. Dakwaan ini digunakan dalam hal terdakwa melakukan beberapa tindak pidana yang masing-masing merupakan tindak pidana yang berdiri sendiri.

e. Dakwaan kombinasi, yaitu surat dakwaan yang mengkombinasikan atau menggabungkan beberapa dakwaan, seperti dakwaan kumulatif dengan dakwaan alternatif atau subsidair.

\section{B. Analisis Tuntutan}

Memberikan tuntutan artinya meminta pertanggungjawaban kepada PT.DGI. Dalam kasus ini, Dudung Purwadi yang merupakan Direktur Utama PT.DGI yang diangkat oleh RUPS Nomor 6 tanggal 8 Januari 2009, meminta bantuan kepada Nazaruddin agar PT.DGI bisa mendapatkan proyek pemerintah. Dalam hal ini, Dudung Purwadi merupakan directing mind berdasarkan Akta Pernyataan Keputusan RUPS Nomor 6 tanggal 8 Januari 2009 yang mengangkat Dudung Purwadi sebagai Direktur Utama, dan juga berdasarkan Pasal 92 Undang-Undang Nomor 40 Tahun 2007 tentang Perseroan Terbatas yang menyatakan bahwa yang menjadi pengurus ialah Direksi. Lalu ketika Dudung Purwadi bertemu dengan Nazaruddin dan meminta bantuan kepadanya, perbuatan tersebut dilakukan atas nama PT.DGI. Hal ini dapat dilihat karena Dudung Purwadi meminta agar PT.DGI bisa mendapatkan proyek pemerintah.

Kemudian atas bantuan Nazaruddin, Dudung Purwadi bisa mendapatkan informasi langsung mengenai pelaksanaan pelelangan proyek Universitas Udayana, dan atas bantuan dari beberapa pihak, PT.DGI akhirnya memenangkan lelang. Tindakan ini tidak sesuai dengan ketentuan yang ada, yang dalam hal ini digunakan peraturan mengenai pengadaan barang/jasa pemerintah karena dana yang digunakan dalam pembangunan proyek Universitas Udayana bersumber dari APBN. Ketentuan peraturan yang digunakan untuk perbuatan Dudung 
Purwadi tersebut ialah Keputusan Presiden Nomor 80 Tahun 2003 jo Peraturan Presiden Nomor 95 Tahun 2007 tentang Pedoman Pelaksanaan Pengadaan Barang/Jasa Pemerintah, karena perbuatan Dudung Purwadi ini terjadi sebelum dilakukannya perubahan terhadap peraturan tersebut, yang di mana sekarang sudah menjadi Peraturan Presiden Nomor 26 Tahun 2018. Sehingga untuk mengidentifikasi perbuatan Dudung Purwadi tersebut masih menggunakan regulasi yang lama.

Di dalam Pasal 3 Keputusan Presiden Nomor 8o Tahun 2003 jo Peraturan Presiden Nomor 95 Tahun 2007 diatur bahwa pelaksanaan lelang harus dilakukan dengan prinsip terbuka dan bersaing serta adil/tidak diskriminatif. PT.DGI memenangkan lelang dengan melanggar ketentuan tersebut karena mendapatkan informasi langsung dari panitia pengadaan dan juga melakukan persekongkolan dengan beberapa pihak.

Dari perbuatan Dudung Purwadi tersebut dapat dilihat bahwa meskipun tidak secara materi, PT.DGI mendapatkan keuntungan yaitu bisa memenangkan pelelangan proyek. Kemudian setelah penandatanganan kontrak dan melakukan pengerjaan proyek, Dudung Purwadi menyatakan telah selesai melaksanakan proyek meskipun pada kenyataannya tidak selesai $100 \%$ dan telah mendapatkan bayaran penuh $100 \%$. Hal ini dilakukan hingga tahap kedua pelaksanaan proyek Universitas Udayana. Dari perbuatan Dudung Purwadi tersebut, PT.DGI mendapatkan keuntungan sebesar Rp.24.778.603.605,oo. Sehingga dengan demikian, PT.DGI tidak hanya diuntungkan dengan memenangkan pelelangan proyek, tetapi juga diuntungkan secara materi yaitu mendapatkan sejumlah uang.

\section{Analisis Dasar Pertimbangan Hakim}

Setelah dilakukan pemeriksaan alat-alat bukti di persidangan, maka kemudian Majelis Hakim melakukan pertimbangan-pertimbangan terhadap alat-alat bukti yang diajukan tersebut untuk kemudian akan mengambil putusan terhadap dakwaan dan tuntutan Penuntut Umum. Untuk alat-alat bukti tersebut, setidaknya Majelis Hakim harus memiliki dua dan memiliki keyakinan bahwa telah benar-benar terjadi suatu tindak pidana yang dilakukan oleh si terdakwa. Dalam kasus PT.DGI, setidaknya ada lebih dari dua alat bukti yang diperoleh, yaitu keterangan saksi, keterangan ahli, keterangan terdakwa, dan surat. Setelah selesai dilakukan pemeriksaan di persidangan, maka majelis hakim akan melakukan musyawarah untuk menghasilkan suatu putusan pengadilan. Selain daripada itu, hakim juga mempertimbangkan unsur-unsur tindak pidana yang diduga dilakukan oleh PT.DGI, yaitu:

Ad. 1. Unsur Setiap Orang

Di dalam Pasal 1 angka 3 Undang-Undang Nomor 31 Tahun 1999 jo Undang-Undang Nomor 20 Tahun 2001 tentang Pemberantasan Tindak Pidana Korupsi diatur bahwa yang termasuk ke dalam setiap orang ialah perseorangan dan korporasi. Dalam hal ini, terdakwa yaitu PT. DGI yang diwakili oleh Djoko Eko Suprastowo selaku Direktur Utama telah membenarkan identitas terdakwa yang terdapat di dalam dakwaan Penuntut Umum. Sehingga dengan demikian, unsur setiap orang telah memenuhi, yaitu berupa korporasi.

Ad. 2. Unsur Secara Melawan Hukum

Oleh karena unsur secara melawan hukum ini termasuk ke dalam melawan hukum secara formil dan materiil, yaitu tidak hanya undang-undang tertulis, tetapi juga tidak tertulis, maka perbuatan PT.DGI telah memenuhi karena melakukan perbuatan sebagai berikut: melakukan pemilihan penyedia barang dan jasa tidak sesuai dengan Keputusan Presiden Nomor 8o Tahun 2003 tentang Pedoman Pelaksanaan Pengadaan Barang/Jasa Pemerintah sebagaimana telah diubah dengan Peraturan Presiden Nomor 95 Tahun 2007, tepatnya melakukan persekongkolan dengan beberapa pihak untuk memenangkan PT.DGI dalam pelelangan, sehingga pelelangan tersebut tidak lagi merupakan pelelangan yang sehat; PT.DGI menyatakan 
proyek telah selesai $100 \%$ sehingga menerima pembayaran $100 \%$, tetapi pada kenyataannya proyek tidak selesai.

Ad. 3. Unsur Memperkaya Diri Sendiri atau Orang Lain atau Suatu Korporasi

Memperkaya diri sendiri artinya menjadikan dirinya menjadi lebih kaya, dalam hal ini PT.DGI menjadi bertambah kaya dengan memperoleh keuntungan dari Pelaksanaan proyek Universitas Udayana dan beberapa proyek lain setidak-tidaknya sejumlah Rp.240.099.133.310,oo. Dari perbuatannya tersebut, PT.DGI memberikan fee kepada Muhammad Nazaruddin sehingga Muhammad Nazaruddin menjadi bertambah kaya dengan total Rp.25.456.523.00o,oo; fee kepada Rizal Abdullah, anggota KPWA dan Panitia Pengadaan sejumlah Rp.164.00o.ooo.ooo,oo. Dengan demikian PT.DGI telah memperkaya dirinya sendiri dan juga orang lain, sehingga unsur ini terpenuhi.

Ad. 4. Unsur Dapat Merugikan Keuangan Negara atau Perekonomian Negara

Berdasarkan Laporan Audit Perhitungan Kerugian Negara dengan Nomor SR-698/ D6/ o1/ 2006, negara mengalami kerugian sejumlah Rp.25.953.784.580,57. Sehingga dengan demikian, unsur ini telah terpenuhi.

Ad.5. Melakukan, Menyuruh Melakukan atau Turut Serta Melakukan Perbuatan

Mengenai perbuatan penyertaan, diisyaratkan ada lebih dari seorang pelaku, baik bertindak sendiri-sendiri maupun bersama-sama/bersekutu atau dengan kata lain apabila dua orang atau lebih bersama-sama melakukan suatu perbuatan pidana yang mana masing-masing pelaku mempunyai peran/saling membantu sehingga selesainya suatu perbuatan. Dalam hal ini PT.DGI yang diwakili oleh Dudung Purwadi menghadiri undangan Muhammad Nazaruddin untuk mengatur kerja sama untuk saling membantu dalam proses pelelangan. Setelah diperoleh kesepakatan, maka diatur sedemikian rupa proses pelelangan sehingga PT.DGI dapat memenangkan lelang. Dalam hal ini, PT.DGI berperan sebagai turut serta melakukan, sehingga unsur ini terpenuhi.

Ad. 6. Unsur Perbuatan Berlanjut

Untuk adanya suatu perbuatan berlanjut, diisyaratkan adanya perbuatan yang sama jenisnya dan dengan tujuan yang sama. PT.DGI dalam memenangkan lelang, meminta bantuan Muhammad Nazaruddin, sehingga Muhammad Nazaruddin mengatur pelelangan sedemikian rupa sehingga PT.DGI dapat memenangkan lelang untuk pembangungan proyek Universitas Udayana. Dan dengan bantuan Mumammad Nazaruddin, serta dengan cara yang serupa, PT.DGI kembali memenangkan beberapa pelelangan proyek. Dengan demikian, unsur ini telah terpenuhi.

\section{Analisis Putusan}

Pembacaan putusan merupakan tahap akhir dari proses persidangan. Berdasarkan Pasal 1 ayat 1 (satu) KUHAP, ada tida jenis putusan yang dapat terjadi sebagai akhir dari persidangan. Pertama, terdakwa dinyatakan secara sah dan meyakinkan bersalah, maka akan dijatuhi hukuman pidana. Kedua, terdakwa tidak terbukti secara sah dan meyakinkan bersalah sehingga terdakwa dinyatakan bebas. Ketiga, perbuatan yang didakwakan kepada terdakwa telah terbukti tetapi perbuatan tersebut bukan merupakan tindak pidana, sehingga terdakwa dinyatakan lepas dari segala tuntutan hukum. Untuk putusan yang menyatakan terdakwa bersalah dan akan dijatuhi sanksi pidana, sanksi pidana yang dapat diberikan kepada terdakwa dapat berupa hukuman pokok saja, atau dapat berupa hukuman pokok ditambah hukuman pidana tambahan.

\section{D.Kesimpulan}

Berdasarkan uraian pendapat dan pembahasan terhadap putusan Nomor 81/Pis.Sus/Tipikor/2018/Pn.Jkt.Pst., maka penulis memperoleh kesimpulan sebagai berikut: 
Pertanggungjawaban pidana korporasi yang dimuat di dalam Undang-Undang Nomor 31 Tahun 1999 tentang Pemberantasan Tindak Pidana Korupsi sebagaimana diubah dengan Undang-Undang Nomor 20 Tahun 2001 tentang Perubahan atas Undang-Undang Nomor 20 Tahun 2001 adalah pertanggungjawaban pidana berdasarkan teori identifikasi dan/atau teori agregasi. Teori pertanggungjawaban identifikasi ini dapat dilihat di dalam Pasal 20, yang menyatakan bahwa perbuatan tersebut harus dilakukan atas nama korporasi oleh orang-orang berdasarkan hubungan kerja yang dapat dilihat di dalam anggaran dasar atau Undang-Undang pendiriannya (sui generis) dan dilakukan dalam lingkungan korporasi. Sedangkan teori agregasi dapat dilihat dari Pasal 20 ayat (2) yang menyatakan bahwa "perbuatan itu dilakukan sendiri maupun bersama-sama."

Pertanggungjawaban pidana korporasi yang melakukan korupsi pengadaan dan jasa studi kasus Putusan Nomor 81/Pid.Sus/Tipikor/2018/Pn.Jkt.Pst, ialah berupa pidana denda sebesar Rp.700.000.00o,oo dan pidana tambahan yaitu membayar uang pengganti sejumlah Rp.85.490.234.737,oo dan mencabut hak PT.DGI untuk mengikuti lelang proyek pemerintah selama 6 (enam) bulan. Pertanggungjawaban ini dimintakan kepada PT.DGI karena perbuatan PT.DGI memenuhi ketentuan teori identifikasi sesuai dengan teori pertanggungjawaban pidana korporasi yang dianut oleh Undang-Undang Pemberantasan Tindak Pidana Korupsi, sehingga PT.DGI dapat dimintakan pertanggungjawaban pidananya.

\section{Daftar Pustaka}

Sutan Remy Sjahdeini, Ajaran Pemidanaan: Tindak Pidana korporasi E Seluk-beluknya, (Jakarta: Kencana, 2017).

Muladi dan Dwidya Priyatno, Pertanggungjawaban Pidana Korporasi, (Jakarta: Kencana, 2010). Mahrus Ali, Asas-asas Hukum Pidana Korporasi, (Jakarta: Rajawali Pers, 2018).

Siallagan, Haposan dan Simamora, Janpatar., Hukum Tata Negara Indonesia, Medan: UD. Sabar, 2011.

Hasbullah F. Sjawie, Pertanggungjawaban Pidana Korporasi pada Tindak Pidana Korupsi, (Depok: Prenadamedia Group, 2018).

\section{Peraturan Perundang-undangan}

Undang-Undang Nomor 31 Tahun 1999 jo Undang-Undang Nomor 20 Tahun 2001 Tentang Pemberantasan Tindak Pidana Korupsi.

Keputusan Presiden Nomor 8o Tahun 2003 Tentang Pedoman Pelaksanaan Pengadaan Barang/Jasa Pemerintah sebagaimana diubah dengan Peraturan Presiden Nomor 95 Tahun 2007.

Peraturan Presiden Nomor 16 Tahun 2018 Tentang Pengadaan Barang/Jasa Pemerintah.

Undang-Undang Nomor 40 Tahun 2007 Tentang Perseroan Terbatas.

\section{Jurnal}

Huzaemah T.Yanggo, "Korupsi, Kolusi, Nepotisme dan Suap (KKNS) Dalam Pandangan Hukum Islam”. Tahkim. Vol. IX No.1, Juni 2013.

Simamora, Janpatar. "Reformasi Birokrasi, Good Governance dan Etika Pelayanan Publik." Jurnal Ilmu Administrasi: Media Pengembangan Ilmu dan Praktek Administrasi, Vol. 10, No. 1 (2013): 39-6o. 
Nommensen Journal of Legal Opinion (NJLO)

Jurnal Magister Hukum Program Pascasarjana Universitas HKBP Nommensen

Volume 02 Nomor 02 Juli 2021 Halaman. 215-231 e-ISSN: 2723-164X p-ISSN: 2722-9858

http://ejournal.uhn.ac.id/index.php/opinion

Simamora, Janpatar, and Haposan Siallagan. "Hans Kelsen's Thoughts On The Authority Model Of The Constitutional Of Indonesia." Journal of Talent Development and Excellence, Vol. 12, No. 1 (2020): 4411-4415.

Simamora, Janpatar., Kepastian Hukum Pengajuan Kasasi oleh Jaksa Penuntut Umum Terhadap Vonis Bebas, Jurnal Yudisial, Komisi Yudisial RI, Vol. 7 No. 1 April 2014, hlm. 117.

\section{Internet}

https://m.hukumonline.com, diakses tanggal 22 April 2020.

https://klinikhukum.id, diakses tanggal 1o Mei 2020. 